those for a technical man. Sir James epigrammatically stated that the object of patent law is to help industry by encouraging progress, by checking progress at each step ; in other words, if there were no patent law and invention continued at its present rate, industry would progress faster; on the other hand, if there were no rewards for invention, the incentive to invent would almost disappear. In his opinion, the cost of patents is too high, and the legal expense entailed in fighting an infringement favours the large company. The appeal system gives rise to anomalies. Thus, the first judge may decide against a patentee, the appeal judges may agree with him, and finally three out of five in the Lords of Appeal might uphold the patentee's claim. We then have the curious position of three judges overruling six.

\section{History of Iron Founding in England}

AT the annual general meeting of the Newcomen Society on November 9, Mr. W. A. Young was elected president for the ensuing year. The membership of the Society now stands at 870. After the conclusion of the business, the first part of a paper by Mr. Rhys Jenkins was read entitled "Iron-founding in England, 1490-1890". Though there are objects of cast-iron to be seen in museums, probably made $1,500-2,000$ years ago, iron-founding in Europe as a regular trade is of comparatively modern origin. In Great Britain iron-founding followed the substitution of the primitive hearth, the bloomery, by the high furnace, known as the blast furnace. Sussex was the cradle of English iron-founding and there is a reference dated 1490 to a payment on behalf of the Archbishop of Canterbury to "ye Ierne founders of Buxstede". The industry was based mainly on the production of war material, though there was a certain amount of production of chimney backs, fire dogs and grave slabs, and also of gear for the forges. King Henry VIII came to the throne in 1509 and he at once set about the provision of armament. He brought over foreign workmen to cast bronze guns, and a year or two prior to his death the first cast-iron guns were made. The credit for initiating this departure belongs to William Levet, the parson of Buxted. In the early days of Elizabeth, an export trade in cast-iron guns commenced. Guns were sent to the Low Countries, France and Germany, and in 1582 Portugal took no fewer than 132 pieces. In 1601 it was stated the total output was about 800 tons per annum. The earliest account of any real value of the methods of casting guns is given by Sirurey de Saint Remy in his "Memoires d'Artillerie" published in Paris in 1693 .

\section{Structure and Strength}

The seventh Andrew Laing Lecture, delivered by Sir William Bragg before the North-East Coast Institution of Engineers and Shipbuilders at Newcastle on November 8 , dealt with the molecular basis of the strength of materials. Taking carbon compounds first, he showed how the regular arrangement of the carbon atoms in the diamond as determined by modern $\mathrm{X}$-ray analysis accounts for its hardness, how long chains of such atoms with side atoms of hydrogen lead to paraffins, the tendency of which to set themselves parallel to each other like corn stalks in a field leads to their slipperiness, and how chains modified by oxygen atoms at one end lead to oils with lubricating powers. Another arrangement of carbon atoms in a plane leads to graphite sheets, which again can slide over each other and also possess lubricating powers. More complicated chain structures give celluloses of many kinds as found in plants, and a combination of benzene rings with oxygen gives plastics like bakelite. The atoms of metals and alloys are in general packed together like spheres, and the properties of the product depend mainly on the sizes of the atoms constituting it and the number of electrons they can put into the common stock.

\section{The Science Museum: Recent Acquisitions}

THE inventor's working model of the first calculating machine capable of multiplying sums of money in sterling currency (f.s.d. and fractions of a penny) has been presented to the Science Museum. The present machine, invented by Mr. E. C. McClure in 1934, requires only one turn of the handle for each digit in the multiplier, so that to multiply any sum of money by a number less than a thousand it is necessary to make only three turns of the handle. The principles embodied in the machine are being used in a new sterling multiplying punch which is being manufactured by Messrs. Powers-Samas Accounting Machines Ltd., who have given the model to the Science Museum. A collection of trade cards issued by English instrument makers to advertise their products, presented by Mr. Thomas H. Court, has recently been placed on exhibition; they are mostly of the eighteenth century and are of considerable historical interest and importance. The Museum has acquired a large-scale working model of the escapement employed about 1880 in the original Waterbury watches, which were among the first really cheap watches to be made. The group of hearing aids illustrates developments since 1930; of special interest are the widely contrasting valve amplifying sets of 1932 and 1938 .

\section{Radio Valve Data}

$\mathrm{EACH}_{\mathrm{ACH}}$ year the Wireless World performs a very useful function in providing comprehensive details of all the thermionic valves available in Great Britain. The issue of November 10 contains a Valve Data Supplement listing more than 1,000 different valves in twenty pages of tables. All types of valves are dealt with, whether these be used as rectifiers, frequency changers or amplifiers ; and while some of those described may be becoming obsolete, it is necessary to include them as they are used for replacement purposes in existing radio sets or amplifiers. In general, the valves are listed in order of filament or heater voltage, and the variation in this voltage is one of the reasons for the large number of valves it is necessary to describe. Valves for battery operation have filaments for 2-volt working, while 
4-volt types are used for A.c. mains operation; the 6.3. and 13-volt types are intended either for universal use on A.C. or D.C. mains, or for use with 6- and 12-volt motor-car batteries respectively. Fortunately, the number of valve bases is not yet equal to the number of valves, but fourteen different bases are listed, of which seven types are in common use in Great Britain, and the text explains that these seven may be connected up in 144 different ways. It is much to be regretted that those responsible for the design and manufacture of valves have not seen their way to bring about some measure of standardization; but in the chaos that exists, the valve data supplement referred to above should prove a useful guide.

\section{Co-ordination of Medical Services}

A DEPUTATION from the central emergency committee of the British Medical Association, including representatives of the Royal Colleges, was received on November 8 by Sir Thomas Inskip, the Minister for Co-ordination of Defence, who was accompanied by officers of the Government departments concerned. The deputation urged the establishment of machinery for the co-ordination of all medical services for the civilian population under a single body, and the coordination of civilian medical organizations under that of the Service Departments. It was also proposed that the machinery should be closely associated with the central emergency committee as being representative of all branches of the profession.

\section{A New Chemical Periodical}

A NEw periodical entitled Chemical Products and the Chemical News, which is being published monthly by Science Services, Ltd., 35 Great James Street, Bedford Row, London, W.C.2, is designed to emphasize the indivisibility of the chemical industry. It will accordingly deal with matters of interest to the chemical, drug, pharmaceutical and cosmetic industries, and particularly the new uses to which chemical products and related materials are being put and their future place in industry and in the framework of the modern world. In this policy, Chemical Products claims to be in the lineage of the Chemical News of Sir William Crookes. The first number (October) includes an article by Dr. E. R. Weidlein, director of the Mellon Institute, on industrial progress, in which developments in the fields of synthetic resins, lubricants and fuels, carbon black, plant stimulants, etc., in which that Institute has been concerned, are reviewed. In other articles A. L. Bacharach reviews the influence of laboratory on manufacturing technique, and C. W. D. Stafford describes the preparation and uses of liver extracts. Dr. W. Langer deals with the formulation of cosmetics, and Dr. C. I. B. Voge with that of mouth washes. An interesting account of the House of Roche is also included, together with the brief views of such eminent chemists as Prof. J. F. Thorpe, Dr. Joseph Needham and Dr. E. F. Armstrong on the nature, scope and policy of a chemical journal.

\section{Colonial Service: Recent Appointments}

THE following appointments have recently been made: F. J. Harper, agricultural officer, Nigeria; G. A. Jones, director of agriculture, Jamaica ; F. H. Fitch, geologist, Malaya; T. G. Chamberlain, veterinary officer, Kenya; D. Slavin, veterinary research officer, Kenya; J. F. C. Swan, veterinary officer, Northern Rhodesia; D. M. Hanschell, assistant botanist, British West Indies Central Sugar Cane Breeding Station, Barbados; W. A. Hughes, inspector of plants and produce, Gold Coast; J. Sheard, sleeping sickness control officer, Nigeria; O. T. Faulkner (director of agriculture, Malaya), principal, Imperial College of Tropical Agriculture, Trinidad (seconded); J. D. Gillespie (agricultural superintendent, British Guiana), agricultural officer, Sierra Leone; B. J. Hartley (district agricultural officer, Tanganyika Territory), agricultural officer, Aden; J. F. Ward (agricultural officer, Nigeria), agricultural officer, British Honduras; A. Cawley (engineering geologist), inspector of mines, Tanganyika Territory.

\section{Announcements}

Sir William BragG, president of the Royal Society, is to deliver an address on "The Advance of Science" at the Ely Diocesan Conference to be held at Cambridge on November 21.

Dr. H. Spencer Jones, Astronomer Royal, will deliver the fourteenth annual Norman Lockyer Lecture under the auspices of the British Association at the Goldsmiths' Hall, London, E.C.2, on Tuesday, December 6, at 4 p.m. The subject of the lecture will be "The Atmospheres of the Planets".

DR. HANS Holfelder, professor of general clinical roentgenology at Frankfort-on-Main, has been awarded the Albers-Schönberg Medal by the German Röntgen Society.

A series of open meetings on "National Defence" has been arranged by the Scientists' Group of the Left Book Club; the meetings are being held at the University Labour Club, 101 Great Russell Street, London, W.C.1, on Mondays at 8.15. Among the topics and speakers are: aerial warfare, by F. W. Meredith, food supplies in war time, by F. Le Gros Clark, the medical services, by Dr. D. Stark Murray and national defence and the scientific worker, by Prof. J. D. Bernal. Particulars can be obtained from the secretary of the Group, 175A Highbury New Park, London, N.5.

AcCording to a special health commission, Poland, which ought to have 25,000 medical practitioners, has only 12,000 , there being about $3 \cdot 7$ per 10,000 inhabitants. 61 per cent are settled in 28 towns which contain only 13.5 per cent of the total population. In order to provide medical attention in rural districts a law is being prepared to compel every medical practitioner to practise in the country for his first two years. 